\title{
Better management of chronic pain care for all
}

$\mathrm{C}$ hronic pain is no respecter of age, wealth or status. Ramage-Morin has estimated that 500000 Canadians aged 12 to 44 years, $38 \%$ of seniors in long-term care facilities and $27 \%$ of seniors living at home experienced pain on a chronic basis. ${ }^{1.2}$ Worse still, a review of the European literature noted that effective pain control for patients in the primary care setting often eluded health practitioners. ${ }^{3}$

Few things in life are as intolerable and incomprehensible as chronic physical pain - a signal meant to alert us to protect our tissues has run amok. In its clutches, we all become irritable, insomniac and anhedonic. It confronts all clinicians and challenges all areas of health care.

Although better research is needed to further our understanding and control of pain, experts agree that much can be done now with newer analgesics, nonpharmacologic techniques such as nerve blocks and physical therapies, as well as spiritual and supportive care. ${ }^{4}$ Availability of quality care for pain is the major problem. Health professionals have not mounted a response commensurate with the magnitude of the problem. Some would even say that access to quality treatment for pain should be considered a human right. ${ }^{5}$

Many factors contribute to the problem of inadequate care for chronic pain - patchy undergraduate and postgraduate training for health professionals; bad experiences with adverse effects from opioids, excessive drug controls and regulations; fear of legal sanctions and myths about addiction; and beliefs that pain is unavoidable in some conditions, that pain is a part of aging and that medications are too costly. ${ }^{5}$ Although the potential for opioid addiction and abuse is real, it is frequently exaggerated. Moreover, this concern is not an acceptable excuse for failure to control chronic pain.

Specialized expertise in management of chronic pain is currently clustered in clinics for chronic pain and palliative care - often found only in large urban hospitals. Services in many areas, especially rural and remote locations, are often sparse, limited in scope or nonexistent. A much broader strategy is required that would involve change in at least three domains: education; technology and tools; and supported selfcare and coaching.

First, education. All health professionals in clinical disciplines should have sufficient skills to diagnose and manage chronic pain. Core competency in this domain should be required not only of undergraduate but also of continuing medical education.

Second, tools and technology. A telemedicine approach using case discussion in care management from a distance may be of benefit. Such networks should be implemented across the country with appropriate program evaluation and remuneration for those providing this assistance. A study of a small-scale program in Ontario by Pronovost and colleagues has shown that the use of telemedicine in the management of chronic pain is cost-effective. ${ }^{6}$ Living a long distance from a tertiary care pain centre should not preclude access to expert advice.

Office-based practice tools and resources for pain care should also be evaluated and, if found useful, should be made widely available. ${ }^{7}$ Such tools could guide the practitioner not only to optimize control of pain but also to minimize the risk for abuse.

Third, supported self-care and lay coaching. Self-management, family and caregiver education, and trained lay coaches all have big potential for filling the gap in basic care for pain. Preliminary evidence by Stinson and colleagues suggests that Internet-based self-management programs with telephone support is effective with disease-specific chronic pain. ${ }^{8}$ Models such as the Strongest Families program in Nova Scotia have shown that nonprofessional coaches, using a manual and expert backup, can help families intervene early for better athome management of problems with behaviour and anxiety, shortening wait times for those in need of more intensive treatment. ${ }^{9}$ Such models need to be evaluated for extension to care for chronic pain.

The availability of care for pain needs improvement. All of us who provide clinical care must step up to do our share. The system also needs to be retooled so that no one is left to suffer in silence.

Noni E. MacDonald MD MSc, Ken Flegel MDCM MSc, Paul C. Hébert MD MHSc; with editorial advisory team member, Matthew B. Stanbrook MD PhD

\section{References}

1. Ramage-Morin PL, Gilmour H. Chronic pain at ages 12 to 44. Health Rep 2010; 21:53-61.

2. Ramage-Morin PL. Chronic pain in Canadian seniors. Health Rep 2008;19:37-52.

3. Smith BH, Torrance N. Management of chronic pain in primary care. Curr Opin Support Palliat Care 2011;5:137-42.

4. Lynch ME, Craig KD, Peng PWH, editors. Clinical pain management: a practical guide. Chichester, West Sussex (UK): Wiley-Blackwell; 2010.

5. Lohman D, Schleifer R, Amon JJ. Access to pain treatment as a human right. BMC Med 2010;8:8.

6. Pronovost A, Peng P, Kern R. Telemedicine in the management of chronic pain: a cost analysis study. Can J Anaesth 2009;56:590-6.

7. Wenghofer EF, Wilson L, Kahan M, et al. Survey of Ontario primary care physicians' experiences with opioid prescribing. Can Fam Physician 2011;57:324-32.

8. Stinson JN, McGrath PJ, Hodnett ED, et al. An Internet-based self-managemen program with telephone support for adolescents with arthritis: a pilot randomized controlled trial. J Rheumatol 2010;37:1944-52.

9. Lingley-Pottie P, McGrath PJ. Telehealth: a child and family-friendly approach to mental health-care reform. J Telemed Telecare 2008;14:225-6.

Competing interests: See www.cmaj.ca/site/misc/cmaj_staff.xhtml.

Affiliations: See www.cmaj.ca/site/misc/cmaj_staff.xhtml.

Correspondence to: CMAJ editor, pubs@cmaj.ca

CMAJ 2011. DOI:10.1503/cmaj.111065 